\title{
Evaluasi Tingkat Pelayanan Bendung Tomatoppe pada Daerah Irigasi Bajo Kabupaten Luwu
}

\section{(Evaluation the Service Level of Tomatoppe weir in the Bajo Irrigation Area, Luwu District)}

\author{
Erna Anryana ${ }^{1 *)}$, Totok Prawitosari ${ }^{2)}$, dan Mahmud Achmad ${ }^{3)}$ \\ 1) Program Studi Keteknikan Pertanian Universitas Hasanuddin \\ 2) Program Studi Keteknikan Pertanian Universitas Hasanuddin \\ ${ }^{3)}$ Program Studi Keteknikan Pertanian Universitas Hasanuddin \\ ${ }^{*}$ Email korespondensi: ernaanryana@gmail.com
}

\begin{abstract}
ABSTRAK
Evaluasi merupakan kesatuan sistem manajemen baik itu perencanaan, pelaksanaan, maupun monitoring. Bendung merupakan salah satu dari sekian banyak aset negara yang seringkali dilakukan evaluasi guna mengetahui kondisi asset tersebut. Evaluasi tingkat pelayanan Bendung Tomatoppe dilakukan untuk mengetahui tingkat pelayanan Daerah Irigasi Bajo dengan membandingkan tingkat pelayanan rencana atau desain awal pada tahun 2009/2010 dan tingkat pelayanan pada tahun 2016 dan 2018. Di Sulawesi Selatan tepatnya Kecamatan Bajo Kabupaten Luwu sebagian besar mayoritas penduduknya merupakan petani, untuk menjamin ketersediaan air di daerah mereka pada tahun 2010 Pemerintah Pusat telah melakukan membangun Bendung Tomatoppe yang berpotensi mengaliri lahan persawahan sebesar 5.829 Ha yang tersebar di beberapa Kecamatan. Prosedur evaluasi dilakukan dengan pengamatan dan pengambilan debit pada saluran primer, sekunder dan tersier terpilih guna mengetahui perbedaan debit rencana dan debit evaluasi. Hasil penelitian menunjukkan pelayanan Bendung Tomatoppe pada tingkat luas tanam dengan jumlah maksimum sebesar 5.691 Ha. Hal ini berbeda dengan rencana awal pembangunan pada tahun 2009 sebesar 5.829 ha. Perubahan nilai debit penelitian dengan dengan debit rencana dapat di sebabkan oleh beberapa faktor yaitu adanya proses sedimentasi, kehilangan air irigasi yang di sebabkan oleh penguapan (evaporasi), serta adanya perubahan desain awal terhadap saluran dan luas area layanan.
\end{abstract}

Kata kunci: Bendung, Tingkat Pelayanan, Debit.

\section{PENDAHULUAN}

\section{Latar Belakang}

Air merupakan komponen yang penting bagi semua mahluk hidup, baik itu manusia, tumbuhan maupun hewan. Tidak dapat di pungkiri manusia akan selalu bergantung akan ketersediaan air. Sebagai salah satu negara yang memiliki wilayah pertanian yang luas, dari tahun ke tahun pemerintah berupaya untuk meningkatkan pembangunan dalam sektor pertanian yang di tunjang dari jaringan irigasi yang layak. Pembangunan maupun pembaharuan secara signifikan terus ditingkatkan guna meningkatkan dan mempertahankan pendapatan petani di bidang pertanian dan standar hidup petani. Begitu pula di tahun 
2009/2010, Anggaran Pendapatan dan Belanja Negara (APBN) di alokasikan untuk pembangunan sarana irigasi.

Bendung merupakan bangunan yang terbuat dari pasangan batu kali, bronjong atau beton, yang terletak melintang pada sebuah sungai. Bendung dapat digunakan untuk berbagai keperluan seperti irigasi area persawahan, sarana pengendalian banjir, serta pembangkit tenaga listrik (Mangore dkk, 2013).

Bendung memiliki area layanan seluas Daerah Irigasi, saluran sekunder memiliki area layanan seluas saluran tersier. Area layanan ini hanya dikenakan pada aset yang mempunyai fungsi ikut mengatur aliran air.

Beberapa penelitian menyebutkan adanya kemungkinan penurunan pelayanan pada area jaringan irigasi yang disebabkan oleh beberapa faktor. Perkiraan tingkat pelayanan area jaringan irigasi harus memiliki dasar, apakah Bendung tersebut dapat mengaliri sektor pertanian di Daerah Irigasi Bajo sesuai dengan sesain awal bendung yang di rencanakan setelah pengoprasiannya.

Berdasarkan penjelasan di atas, maka perlu dilakukannya penelitian tentang bagaimana tingkat pelayanan jaringan irigasi pada bendung tersebut apakah mengalami penurunan atau peningkatan pelayanan.

\section{Tujuan Penelitian}

Tujuan dari penelitian ini adalah mengetahui tingkat pelayanan Daerah Irigasi Bajo dengan membandingkan tingkat pelayanan rencana atau desain awal pada tahun 2009/2010 dan tingkat pelayanan pada tahun 2016 .

\section{METODOLOGI PENELITIAN}

\section{Waktu dan Tempat}

Pengambilan data penelitian Studi Evaluasi Tingkat Pelayanan Daerah Irigasi Bajo dimulai pada tanggal 25-27 Maret 2016, di Bendung Tomatoppe, dan daerah irigasi Bajo, Kabupaten Luwu, Sulawesi Selatan.

\section{Metode Pengumpulan Data}

Dalam penelitian yang akan dilakukan diperlukan beberapa data yang merupakan hasil pengukuran dan data yang telah dilakukan beberapa dinas terkait yang meliputi:

1. Data Potensi Lahan Sawah Irigasi di peroleh dari Dinas Dinas Pekerjaan Umum dan Perumahan Rakyat Kabupaten Luwu

2. Data Debit Tahun 2015 peroleh dari Dinas Pekerjaan Umum dan Perumahan Rakyat Kabupaten Luwu

3. Desain Awal Perencanaan Bendung Tomatoppe peroleh dari Departemen Pekerjaan Umum, Ditjen SDA Balai Besar Wilayah Sungai Pompeng Makassar.

4. Data Curah Hujan selama 10 tahun terakhir diperoleh dari BPP Kecamatan Bajo, BPP Kecematan Belopa dan Belopa Utara.

5. Data Klimatologi Kabupaten Luwu dari tahun 2009-2017 diperoleh dari Balai Besar Wilayah Sungai Pompeng Makassar.

6. Data Luas Tanam dan Panen Sawah Irigasi diperoleh dari Dinas Pertanian Tanaman Pangan: Peternakan Dan Holtikultura Kabupaten Luwu.

\section{Prosedur Penelitian} adalah:

Adapun langkah kerja penelitian

1. Mendeskripsikan jaringan irigasi yang meliputi:

a. Letak dan luas daerah irigasi

b. Spesifikasi saluran irigasi berupa:

- Saluran Irigasi Primer

- Saluran Irigasi Sekunder

- Saluran Irigasi Tersier

2. Menganalisis data Curah Hujan selama 10 tahun terakhir

3. Menghitung curah hujan efektif dengan rumus dibawah:

$$
R e=70 \% \times \frac{1}{15} R_{80}
$$

Keterangan:

$\operatorname{Re}=$ Curah hujan efektif $(\mathrm{mm})$ 
$\mathrm{R}_{80}=$ Curah hujan dengan probabilitas $80 \%(\mathrm{~mm})$

$70 \%=$ Untuk tanaman padi

4. Menghitung kebutuhan air irigasi untuk padi dengan rumus dibawah:

$$
I R=\frac{N F R}{e}
$$

Keterangan:

IR = Kebutuhan air irigasi ( $\mathrm{mm} / \mathrm{hari})$

NFR =Kebutuhan bersih air di sawah ( $\mathrm{mm} / \mathrm{hari})$

e $=$ Efisiensi irigasi secara keseluruhan

5. Menghitung debit aliran air pada saluran primer, sekunder dan tersier pada daerah irigasi sebagai berikut:

a. Saluran Irigasi Primer Bajo

b. Saluran Irigasi Sekunder Langkidi 2

Saluran Tersier Langkiddi

c. Saluran Irigasi Sekunder Jambu 2

Saluran Tersier Jambu

dengan rumus dibawah:

$$
Q=A x V
$$

Keterangan:

$\mathrm{Q}=$ Debit air $\left(\mathrm{m}^{3} / \mathrm{s}\right)$

A $=$ Luas penampang saluran $\left(\mathrm{m}^{2}\right)$

$\mathrm{V}=$ Kecepatan aliran $(\mathrm{m} / \mathrm{s})$.

6. Menganalisa Data Luas Tanam dan Panen Sawah Irigasi pada Daerah Irigasi Bajo sebelum dan setelah dioprasionalkan bendungan.

7. Melakukan evaluasi tingkat pelayanan dengan membandingkan tingkat pelayanan rencana tahun 2009 dan tingkat pelayanan pada tahun 2016.

\section{Bagan Alir Penelitian}

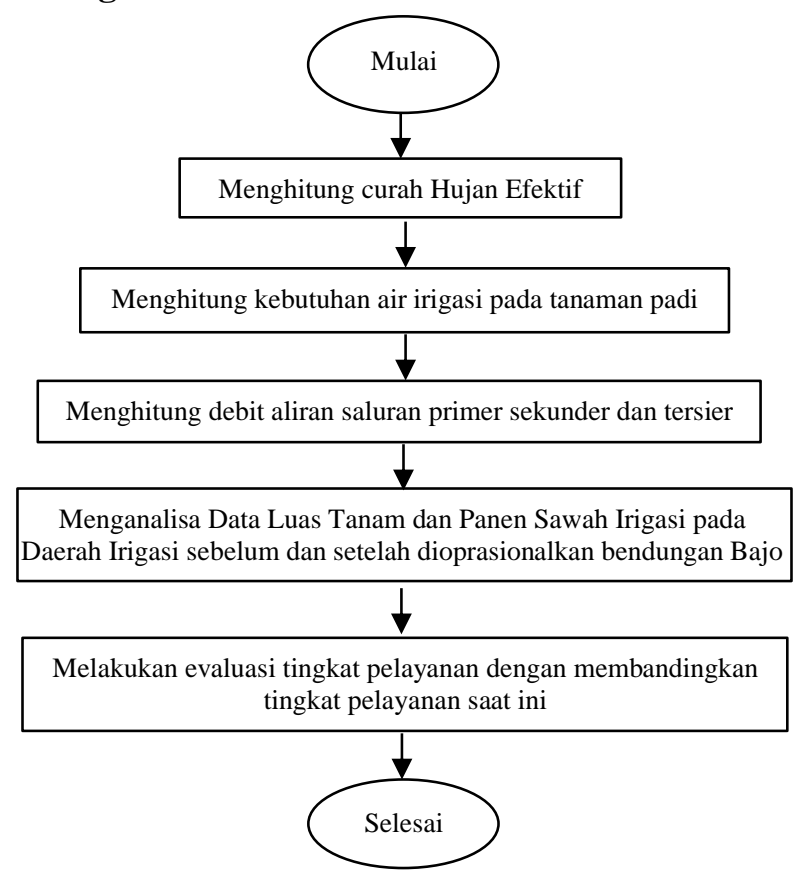

Gambar 1. Bagan Alir Penelitian

HASIL DAN PEMBAHASAN

\section{Keadaan Umum Wilayah \\ Letak dan Iklim}

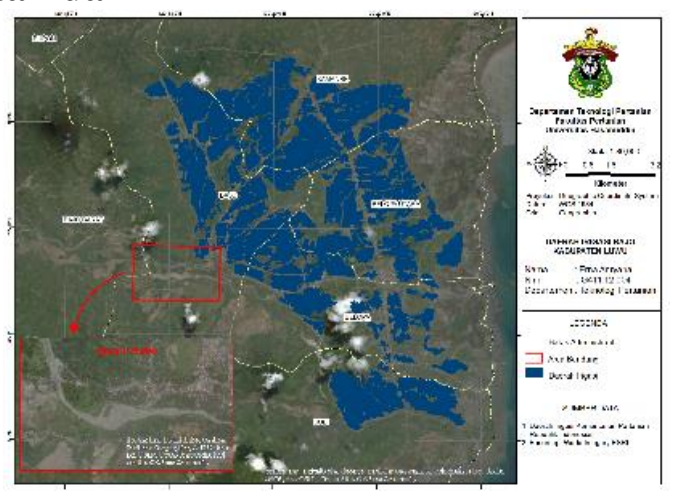

Gambar 2. Daerah Irigasi Bajo

Bendung Tomatoppe berlokasi di Desa Rumaju Kecamatan Bajo Kabupaten Luwu dan jaringan irigasi Bajo terletak di Kecematan Bajo, Belopa, Belopa Utara, Kamanre, dan Suli. Secara geografis daerah irigasi Bajo berada pada $03^{\circ} 23^{\prime} 15^{\prime \prime}$ LS sampai $03^{\circ} 20^{\prime} 45 \mathrm{LS}$ dan $120^{\circ} 17^{\prime} 15^{\prime \prime} \mathrm{BT}$ sampai $120^{\circ} 24^{\prime} 30^{\prime \prime}$ BT. Daerah Kawasan Bendung Tomatoppe beriklim tropis yang memiliki musim penghujan yang berlangsung pada bulan November sampai bulan Mei serta musim kemarau yang berlangsung pada bulan Juni sampai bulan Oktober. Suhu rata-rata berkisar antara 
$24^{\circ} \mathrm{C}$ sampai $27^{\circ} \mathrm{C}$, rata-rata hujan tahunan $2.341 \mathrm{~mm}$ atau berkisar antara $1.143 \mathrm{~mm}$ sampai $4.623 \mathrm{~mm}$. Sumber air utama untuk daerah irigasi Bajo adalah sungai Bajo (Sungai Suso), dengan beberapa anak sungai seperti Salu Ranteballa, Salu Bone, dan Salu Kompi yang bersumber dari pegunungan Latimojong.

\section{Kondisi Bendung Tomatoppe}

Bendung Tomatoppe telah beroprasi pada tahun 2010, sebelum dilakukan perbaikan, pengambilan air guna mengaliri daerah sekitar ialah dengan menggunakan bendung yang terbuat dari bronjong. Bendung bronjong yang ada dari tahun ketahun mengalami kerusakan yang diakibatkan oleh banjir sehingga fungsi bendung semakin menurun sehingga bendung bronjong yang ada digantikan dengan bendung tetap. Bendung Tomatoppe memiliki lebar sebesar 100,20 $\mathrm{m}$ dengan panjang saluran induk seluas $4.530 .00 \mathrm{~m}$, panjang saluran sekunder $64.220 .00 \mathrm{~m}$ dan petak tersier $109 \mathrm{bh}$.

\section{Profil Saluran}

Saluran primer Bajo memiliki luas daerah tangkapan sebesar 5.829 Ha. Berdasarkan hasil pengukuran lapangan diketahui lebar saluran primer BBj. 2 adalah $5.96 \mathrm{~m}$, dan memiliki kedalaman sekitar 56 sampai $65 \mathrm{~cm}$.

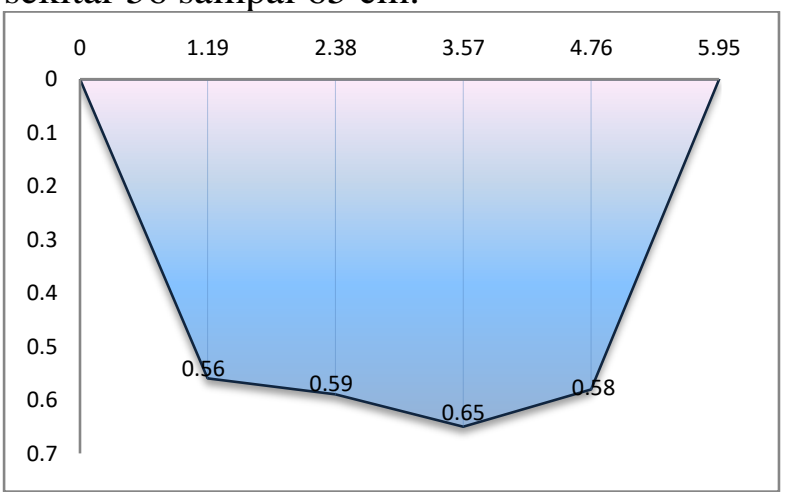

Gambar 3. Penampang Saluran Primer Bajo BBj. 2

Saluran sekunder Langkiddi pada DI Bajo memiliki luas daerah tangkapan sebesar 1.109 Ha. Pada saluran sekunder Langkiddi BL.2 diketahui memiliki lebar saluran $3.12 \mathrm{~m}$, dan memiliki kedalaman sekitar 33-34 cm.

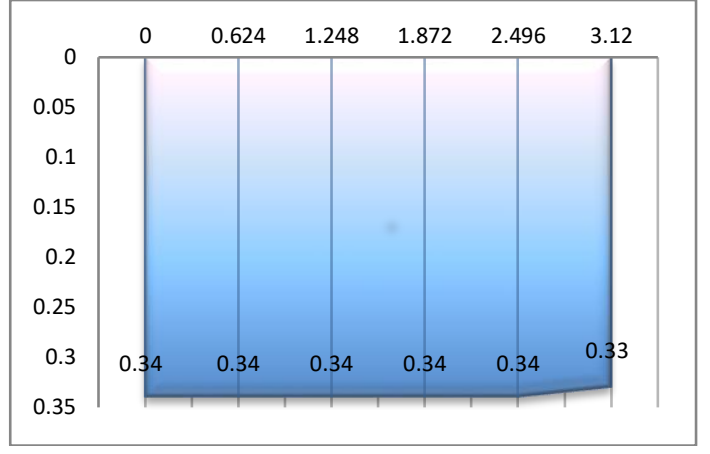

Gambar 4. Penampang saluran sekunder Langkiddi BL.2

Saluran sekunder Jambu BJ.2 diketahui memiliki panjang saluran $2.32 \mathrm{~m}$, dan memiliki kedalaman sekitar 41 sampai 39 $\mathrm{cm}$.

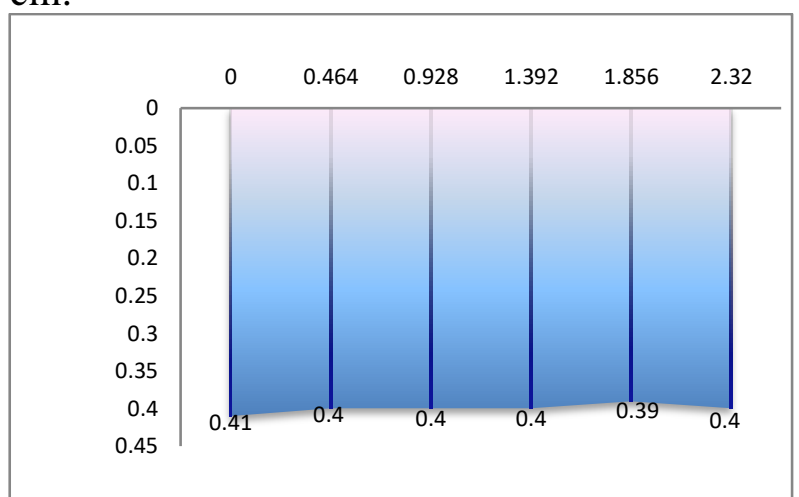

Gambar 5. Penampang Saluran Sekunder Jambu BJ. 2

\section{Analisis Hidrologi \\ Curah Hujan Wilayah}

Curah hujan wilayah diperoleh dari pengolahan data curah hujan harian dari tiga stasiun pencatat curah hujan yaitu stasiun Bajo, stasiun Belopa Utara dan stasiun Belopa dengan jarak $7 \mathrm{~km}^{2}$ di sepanjang stasiun.

Sesuai pendapat Kusuma dkk (2012), bahwa untuk menghitung curah hujan wilayah harus berdasarkan dari perkiraan beberapa titik pengamatan curah hujan, dimana dalam perhitungan curah hujan wilayah ditentukan berdasarkan luas daerah jangkauan. Dalam kasus ini digunakan metode Polygon Thiessen, hal ini dikarenakan luas daerah pengamatan sekitar $700 \mathrm{~km}^{2}$ pada setiap stasiun curah hujan, maka diperoleh hasil curah hujan rata-rata untuk tiap tahunnya seperti tabel berikut: 
Tabel 1. Hasil Perhitungan Curah Hujan Rata-Rata Menggunakan Metode Polygon Thiessen.

\begin{tabular}{cc}
\hline Tahun & Curah Hujan Rata-Rata $(\mathrm{mm})$ \\
\hline 2009 & 199,29 \\
2010 & 445,94 \\
2011 & 335,97 \\
2012 & 301,16 \\
2013 & 412,36 \\
2014 & 374,87 \\
2015 & 310,95 \\
2016 & 352,61 \\
2017 & 358,71 \\
2018 & 280,90 \\
\hline
\end{tabular}

Dari Tabel hasil perhitungan curah hujan rata-rata dari tahun 2009 sampai tahun 2018, diperoleh curah hujan tertinggi terjadi pada tahun 2010 dengan curah hujan rata-rata sebesar 445,941 mm. Sedangkan curah hujan rata-rata yang memiliki intensitas terrendah adalah pada tahun 2009 dengan curah hujan rata-rata sebesar 199,298 mm.

\section{Curah Hujan Efektif}

Data curah hujan yang diperlukan untuk menentukan curah hujan efektif daerah irigasi Tomatoppe adalah data hujan dengan kemungkinan terpenuhi $80 \%$ dan kemungkinan tak terpenuhi $20 \%$, berdasarkan data curah hujan yang ada. Data curah hujan bulanan yang ada sepanjang pengamatan diurutkan dari kecil kebesar berdasarkan jumlah curah hujan pertahunnya.

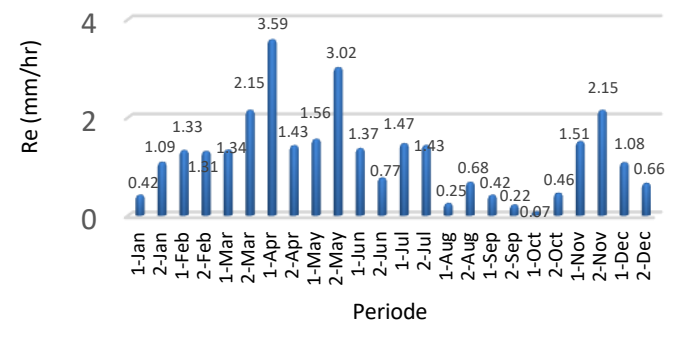

Gambar 6. Grafik curah hujan efektif komoditi padi

\section{Analisis Kebutuhan Air Tanaman}

Dalam menghitung kebutuhan air irigasi, diperlukan data curah hujan efektif yang sudah diperoleh dari perhitungan sebelumnya, data evapotranspirasi acuan $\left(\mathrm{ET}_{\mathrm{o}}\right)$ yang diperoleh dari software CROPWAT 8.0 dengan memasukkan data suhu minimum, suhu maksimum, kelembapan rata-rata, lama penyinaran dan kecepatan angin. Berdasarkan Priyonugroho (2014), CROPWAT dimaksudkan sebagai alat yang praktis untuk menghitung laju evapotranspirasi standar, serta data koefisien tanaman (Kc) menggunakan acuan menurut FAO.

Tabel 2. Kebutuhan air tanaman

\begin{tabular}{ccc}
\hline Masa Tanam & Periode & IR (mm/hari) \\
\hline MT Padi 1 & 1-Mei & 10,08 \\
& 2-Mei & 9,91 \\
& 1-Jun & 8,77 \\
2-Jun & 14,76 \\
1-Jul & 9,86 \\
2-Jul & 14,73 \\
& 1-Ags & 12,37 \\
2-Ags & 10,18 \\
& 1-Sep & 13,27 \\
2-Sep & 18,66 \\
\hline MT Padi 2 & 1-Nov & 10,94 \\
& 2-Nov & 10,03 \\
& 1-Des & 11,09 \\
2-Des & 16,51 \\
& 1-Jan & 10,71 \\
2-Jan & 9,55 \\
1-Feb & 10,72 \\
2-Feb & 13,83 \\
1-Mar & 10,61 \\
2-Mar & 14,43 \\
\hline
\end{tabular}

Dari hasil yang diperoleh pada tabel 2, dapat dilihat Daerah Irigasi Bajo dengan pola tanaman padi-padi dimulai dari awal pengolahan lahan pada bulan April maka diketahui kebutuhan air untuk tanaman maksimum sebesar 18,88 $\mathrm{mm} /$ hari yang terjadi pada bulan September periode ke-2 sedangkan untuk kebutuhan irigasi minimum sebesar $8,77 \mathrm{~mm} /$ hari pada bulan juni periode pertama. Hal tersebut terjadi karena adabya faktor klimatologi dimana pada bulan September terjadi kekurangan air hal ini terlampir pada gambar 6, sehingga kebutuhan air untuk tanaman pada periode ini juga besar.

\section{Debit}

Perhitungan debit dilaksanakan pada beberapa titik saluran yang berada di daerah irigasi Bajo, hal ini dilakukan sebagai data verifikasi dengan data debit yang ada di kantor pengelola bendung Tomatoppe. Dari 
perhitungan lapangan pada tahun 2016 di peroleh data yang berbeda dari data dari kantor pengelolaan pada tahun 2015. Hasil perhitungan debit yang di peroleh dari pengambilan data lapangan adalah sebagai berikut:

Tabel 3. Debit Aliran Saluran Penelitian

\begin{tabular}{lcc}
\hline \multicolumn{1}{c}{ Nama Saluran } & \multicolumn{2}{c}{ Debit $\left(\mathrm{m}^{3} / \mathrm{s}\right)$} \\
\cline { 2 - 3 } & $\begin{array}{c}\text { Februari } \\
2015^{*}\end{array}$ & $\begin{array}{c}\text { Maret } \\
2016^{* *}\end{array}$ \\
\hline $\begin{array}{l}\text { Saluran Primer Bajo } \\
\text { BBj. 2 }\end{array}$ & 3,240 & 4,141 \\
Saluran Sekunder & 1,734 & 1,207 \\
Langkiddi BL.2 & & \\
Saluran Tersier & 0,019 & 0,055 \\
$\begin{array}{l}\text { Langkiddi BL.4 Ki } \\
\text { Saluran Tersier }\end{array}$ & 0,018 & 0,069 \\
$\begin{array}{l}\text { Langkiddi BL.4 Ka 1 } \\
\text { Saluran Sekunder Jambu } \\
\text { BJ.2 }\end{array}$ & 0,605 & 2,990 \\
$\begin{array}{l}\text { Saluran Tersier Jambu } \\
\text { J.2 Ka }\end{array}$ & 0,015 & 0,031 \\
$\begin{array}{l}\text { Saluran Tersier Jambu } \\
\text { J.3 Ka }\end{array}$ & 0,042 & 0,104 \\
\hline
\end{tabular}

Dari semua data diatas dapat dilihat sebagian besar saluran memiliki debit aliran yang berbeda, adanya perbedaan pada saluran primer dan sekunder dapat disebabkan oleh beberapa faktor antara lain sedimentasi atau pendangkalan saluran yang berada pada saluran primer, curah hujan pada daerah sekitar saluran, kehilangan air irigasi yang di sebabkan oleh penguapan (evaporasi) pada permukaan air dan oleh rembesan air yang menyerap pada dinding saluran, serta adanya kehilangan energi bangunan dan kondisi bangunan yang selama 1 tahun terakhir semakin menurun.

\section{Analisa Luas Tanam dan Panen Sawah Irigasi}

Berdasarkan data yang diperoleh dapat di lihat bahwa adanya peningkatan yang signifikan pada luas tanam dan luas panen pada Daerah Irigasi Bajo. Sebelum adanya bendung terlihat luas tanam pada tahun 2007 sebesar 3.655 ha, tahun 2008 sebesar 3.804 ha, dan tahun 2009 sebesar 3.567 ha dengan luas daerah panen hanya berkisar 86-72\% dari luas tanam, banyaknya lahan yang tidak tertanam disebabkan karena kurangnya pasokan air untuk lahan persawahan warga sehingga hasil produksi tanaman pun tidak optimal.

Berbeda dengan tahun-tahun setelah berdirinya bendung, dapat dilihat dari luas luas daerah panen tidak berbedah jauh dengan luas tanam dengan luas daerah panen berkisar 99-96\% dari luas tanam. Adanya perbedaan luas tanam dan luas panen diakibatkan kondisi iklim yang buruk seperti angin kencang dan hama penyakit yang menyerang tanaman padi. Ketersediaan air untuk persawahan dapat di penuhi meskipun pada tahun-tahun yang memiliki kemarau panjang (curah hujan rara-rata terendah) terlihat pada curah hujan rata-rata dengan menggunakan metode Polygon Thiessen pada tahun 2018. Peningkatan luas tanam dan luas penen membawa dampak positif bagi masyarakat daerah setempat yang mendukung peningkatan produksi pangan.

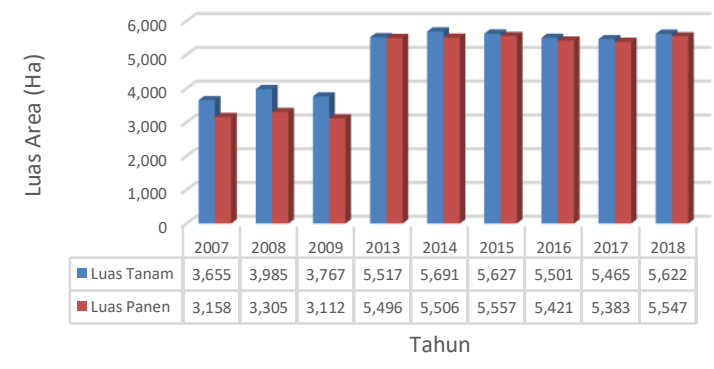

Gambar 7. Grafik Luas Tanam dan Panen Daerah Irigasi Bajo Sebelum dan Setelah Didirikan Bendung Tomatoppe

\section{Evaluasi Tingkat Pelayanan Rencana dan Pelayanan Saat Ini}

Tabel 4. Hasil Evaluasi Tingkat Pelayanan Rencana dan Pelayanan Saat Ini

\begin{tabular}{ccclll}
\hline \multicolumn{1}{c}{$\begin{array}{c}\text { Lahan } \\
\text { Sawah (Ha) }\end{array}$} & \multicolumn{2}{c}{$\begin{array}{c}\text { Pola Tanam } \\
\text { Dan } \\
\text { Intensitas } \\
(\%)\end{array}$} & \multicolumn{2}{c}{ Debit $\left(\mathrm{m}^{3} / \mathrm{s}\right)$} \\
\hline $\begin{array}{c}\text { Renc } \\
\text { ana }\end{array}$ & $\begin{array}{c}\text { Eva } \\
\text { luas }\end{array}$ & $\begin{array}{c}\text { Renc } \\
\text { ana }\end{array}$ & $\begin{array}{c}\text { Eval } \\
\text { uasi }\end{array}$ & Rencana & $\begin{array}{l}\text { Evaluasi/R } \\
\text { ealisasi }\end{array}$ \\
\hline 5.82 & 5.03 & MT1 & MT1 & Saluran & Saluran \\
9 & 7 & $:$ & :Padi & Primer & Primer \\
& & Padi & 100 & BBJ. 2 : & BBJ. 2 : \\
& & 100 & $\%$ & $4,14 \mathrm{~m}^{3} / \mathrm{s}$ & $3,240 \mathrm{~m}^{3} / \mathrm{s}$ \\
& & & L. saluran : & L. saluran : \\
& & & MT2 & $190,00 \mathrm{~m}$ & $0.782,5 \mathrm{~m}$ \\
& & & Area: & Area: \\
\hline
\end{tabular}




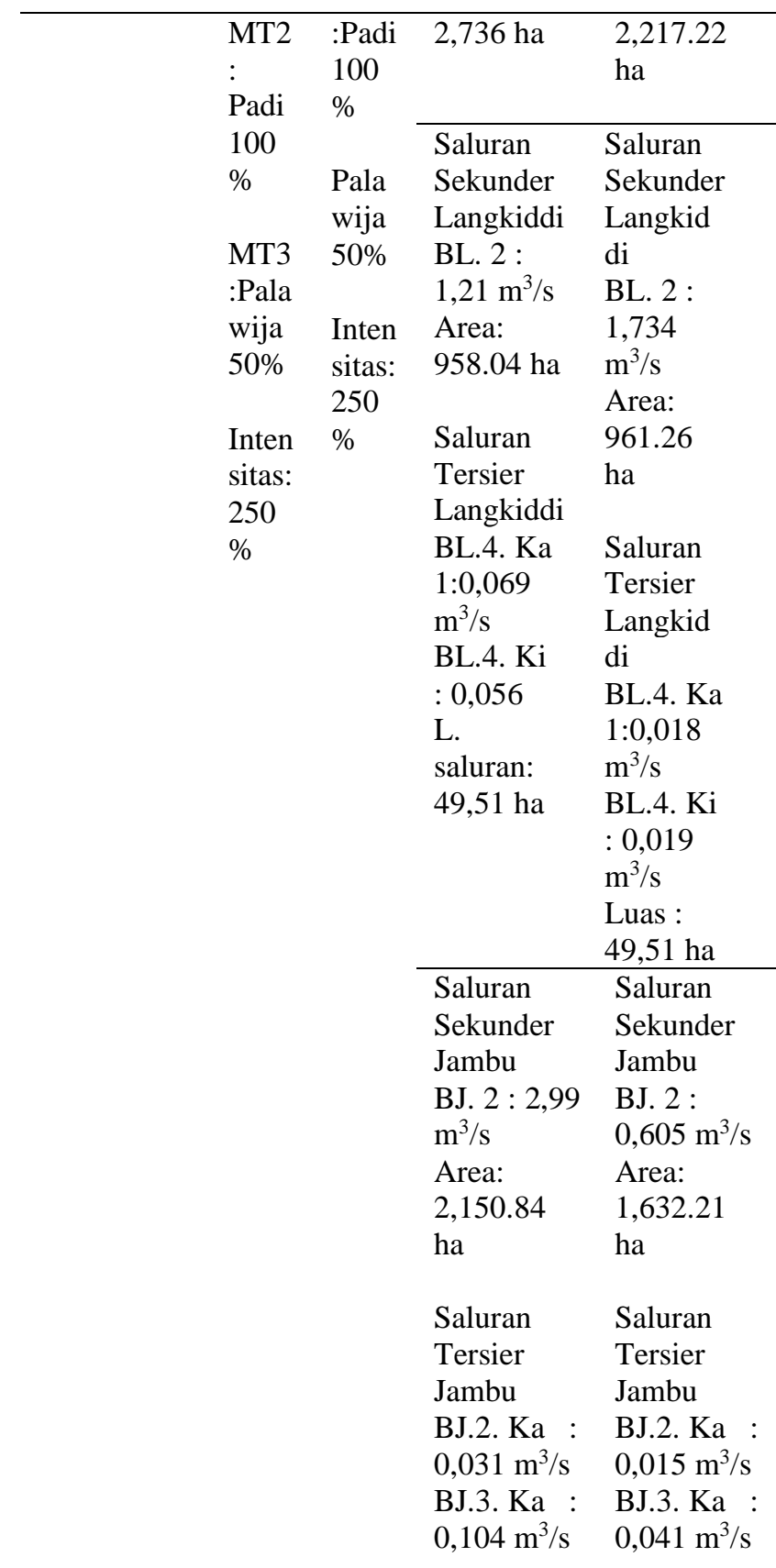

Berdasarkan evaluasi yang telah dilaksanakan diketahui pada gambar 7, dari rencana luas tanam $5.829 \mathrm{Ha}$ hanya biasa dicapai maksimum 5.691 Ha pada tahun 2014. Dengan demikian maka tingkat pelayanan dari segi luas tanam mencapai 97 $\%$.

Untuk pola tanam sedikit berbeda dengan rencana awal. Pada rencana awal pola tanam diisi dengan MT 1 padi, MT 2 padi dan MT 3 palawija. Sedang kenyataannya daerah tersebut hanya memiliki 2 musim tanam yaitu MT 1 dan MT 2 dengan komuditas tanaman padi.
Tanaman palawija (jagung) tidak memiliki musim tanam yang pasti pada daerah ini. Tanaman palawija (jagung) hanya sebagai tanaman sampingan yang di tanam oleh warga untuk mengisi kokosongan lahan pada area persawahan mereka seperti di pematang sawah.

Untuk intensitas tanaman pada musim tanam 1 dan 2 sesuai dengan rencana awal yaitu $100 \%$ untuk masing-masing masa tanam 1 dan 2. Untuk tanaman palawija (jagung) sebesar 50\%. Hal ini diverifikasi oleh Dinas Pekerjaan Umum dan Perumahan Rakyat Kabupaten Luwu dan Dinas Pertanian Tanaman Pangan: Peternakan Dan Holtikultura Kab. Luwu.

Berdasarkan data yang diperoleh diketahui adanya perubahan nilai debit rencana dengan debit realisasi saat ini pada saluran primer dan sekunder, berbeda dengan saluran tersier yang memiliki nilai debit yang sama dari rencana dan realisasi, seperti yang terlihat pada tabel 3 . Berdasarkan tabel tersebut diketahui adanya berbedaan luas saluran rencana dengan luas saluran realisasi sehingga area yang dialiripun akan berbeda dari rencana awal.

Untuk debit saluran yang mengalami perubahan lebih kecil dari rencana (saluran primer BBJ. 2, saluran sekunder Jambu BJ. 2, saluran tersier Jambu BJ.2 dan BJ.3. Ka, saluran tersier Langkiddi BL.4 Ka 1 dan BL. $4 \mathrm{Ki}$ ) disebabkan karena adanya proses sedimentasi dan pengurangan luas lahan. Untuk debit saluran yang mengalami perubahan lebih besar dari rencana (saluran sekunder Langkiddi BL.2) oleh adanya tambahan desain awal terhadap saluran dan luas area layanan.

\section{KESIMPULAN}

Berdasarkan analisis yang telah dilakukan dapat ditarik kesimpulan bahwa:

1. Bendung Tomatoppe memiliki daerah layanan pada tingkat luas tanam dengan jumlah maksimum sebesar 5.691 Ha. Hal ini berbeda dengan rencana awal pembangunan pada tahun 2009 sebesar 5.829 ha. 
2. Perubahan nilai debit dengan dengan debit rencana disebabkan oleh adanya perubahan desain awal terhadap saluran dan luas area layanan.

3. Selama 6 tahun pengoprasian bendung Tomatoppe mengalami penurunan tingkat layanan, meski tidak signifikan dari desain actual bendung. Banyaknya saluran irigasi yang belum permanen mengakibatkan kurang optimalnya pengairan di Daerah Irigasi Bajo.

\section{DAFTAR PUSTAKA}

Kusuma, Olvi P.U., Rispiningtati dan Sayekti, R.W. 2012, Studi Penentuan Skala Prioritas Peningkatan Kinerja Jaringan Irigasi. Jurnal Teknik Pengairan. Volume 3, Nomor I, Mei 2012.

Mangore, V.R., E. M. Wuisan, L. Kawet, H. $\quad 2013$. Perencanaan Bendung Untuk Daerah Irigasi Sulu. Universitas Sam Ratulangi Manado. Vol.1 No.7, Juni 2013 (533-541) ISSN: 2337-6732

Priyonugroho, Anton. 2014. Analisis Kebutuhan Air Irigasi (Studi Kasus Pada Daerah Irigasi Sungai Air Keban Daerah Kabupaten Empat Lawang). Fakultas Teknik Universitas Sriwijaya. Vol.2.No.3, September 2014 ISSN: 2355-374x 